Original Research Article

\title{
The effect of student centered pharmacology teaching in the form of clinical case scenario among M.B.B.S students
}

\author{
G. Francis Britto ${ }^{1}$, K. R. Subash ${ }^{2}$
}

\begin{abstract}
${ }^{1}$ Department of Pharmacology, IRT-PMC, Sanatorium (post), Perundurai, Erode, Tamilnadu, India

${ }^{2}$ Department of Pharmacology, SVIMS-Sri Padmavathi Medical College for Women, SVIMS University, Tirupati, Andhra Pradesh, India
\end{abstract}

Received: 16 December 2016 Accepted: 06 January 2017

\section{*Correspondence to:}

Dr. G. Francis Britto,

Email: stbritto@hotmail.com

Copyright: (C) the author(s), publisher and licensee Medip Academy. This is an openaccess article distributed under the terms of the Creative Commons Attribution NonCommercial License, which permits unrestricted noncommercial use, distribution, and reproduction in any medium, provided the original work is properly cited.

\begin{abstract}
Background: Pharmacology teaching by conventional method is by didactic lectures and practical sessions. To cultivate interest and motivate students towards self directed learning, the best tool in teaching learning methodology available is case based learning. Aims and objective of the study was to analyze the effectiveness and acceptance of case based learning (CBL) of pharmacology among M.B.B.S Students.

Methods: The second year M.B.B.S Students of the academic year 2014 and 2015 were enrolled in the study. Clinical case scenario was formulated as modules based on the common clinical cases which the student observe and encounter in clinical postings in wards. The students were divided in to four groups, 30 in each group with one facilitator. Each module of case based learning was evaluated with pre test and post test. The student perception was recorded by a five point likert scale feedback questionnaire at the end of the study.

Results: The post test scores in all modules revealed significant improvement in student's performance by CBL method when compared using "paired t test". Majority of the students preferred more CBL sessions for rest of the academic year.

Conclusions: Students centred pharmacology teaching by CBL method creates self-directed learning environment to explore more for better understanding and application of the theoretical knowledge gained towards clinical practice.
\end{abstract}

Keywords: Case based learning, Feedback, M.B.B.S students, Pharmacology

\section{INTRODUCTION}

Pharmacology is ever growing with new drugs and new biological targets year after year, due to which the subject is rapidly updating by modern research contributions leading to better drugs with varied mechanism of action and minimal side effects. Hence understanding pharmacological concepts to its roots is important with continued learning and updating habits for better understanding, application and performance at clinical setting. The traditional teaching method in pharmacology is by didactic lectures followed by practical and this method does not help much to integrate the theoretical knowledge and clinical applications. The teacher centered approach is always unidirectional and does not cultivate analytical skills or lifelong self learning, enquiry and problem solving skills.

To bridge the gap between theory and clinical application, to introduce and impart active learning habits, the ideal teaching and learning methodology tool could be Case-based Learning (CBL). CBL provokes the learner to identify the importance of theoretical application of knowledge and creates interest to comprehend and solve the problem by self directed learning which is student centered learning. 
The present study aims to identify the actual impact of student centered learning by CBL as a teaching-learning methodology tool.

\section{METHODS}

The study participants are 60 second year MBBS students and participation was voluntary, conducted in Department of Pharmacology IRT-PMC, Sanatorium (post), Perundurai, Erode, Tamilnadu. Prior permission obtained from appropriate authority in department of pharmacology and approval from department medical education unit. The CBL modules exposed to students are designed from most commonly student encountered clinical problems at our hospital outpatient and wards. The study period was about 3 months from June 2015 to august 2015 .

CBL modules on Bronchial asthma, Acid peptic disease, Myocardial Infarction and Diabetes mellitus were designed by facilitator during April-May 2015 student summer vacation and kept ready for implementation. The example of group dynamics were role played to the students and the topics were informed to the students 2 days before the discussion. The students were divided into the three groups of 20 each. For each group, a faculty member was allotted as a facilitator. Each group exposed to one module had two sittings one week apart with facilitators by CBL method. In the first sitting, the group was facilitated to discuss clinical case scenario problem identification, encouraged to formulate learning issues and its management. At the end of first sitting the facilitators summarize the key points and learning objective to the group for the second sitting along with instructions regarding reference resources and learning materials for encouraging self-study habit before appearing to second sitting of the same module. During the second sitting on the same module after a gap of one week a recap session was initiated by facilitator and the group was allowed to discuss management of co-morbid conditions, complications and drug related updates.

At the end, all three groups are encouraged to have intergroup discussion and facilitators were present to moderate discussion in right track and to clarify doubts. At the end after completing all modules the study participants are requested to fill the feedback questions without mentioning their name and registration number to evaluate their perception, experience and opinion about CBL. A free column is left in the questionnaire for student to provide their opinion regarding CBL. The responses from the questionnaire was graded as strongly agree, agree, no opinion, disagree, and strongly disagree.

The Assessment of student's performance was done by providing same set of multiple choice questions before and after CBL on the modules and the results is compared statistically.

\section{Statistics}

The pre-test and post test scores of CBL is compared by "paired t-test" utilizing Graph pad Instat software Version 3.1 (U.S.A). A P value < 5\% was considered to be statistically significant. The feedback questionnaire was evaluated, and responses obtained were analyzed in percentage using MS Excel software.

\section{RESULTS}

The post-test performance when compared to pre-test performance of $\mathrm{CBL}$ in all three modules shows a statistically significant increase in post test scores (Table 1).

Similarly the results from feedback questionnaire with five point likert scales by study participants revealed $95 \%$ agreed $\mathrm{CBL}$ has improved communication skills, analytical skills and self-learning methods (Table 2).

\section{DISCUSSION}

The student's participation was consistent from beginning to end in all CBL sessions. Majority of the students actively provided the feedback which gave more insight regarding their interest and pave way to design better teaching learning-methods that would improve students' performance. A few medical schools in India have incorporated such teaching learning methods with successful results. ${ }^{3-5}$ Creating self-interest in active reading in the students being the goal, the $\mathrm{CBL}$ is a promising tool.

Table 1: Pre test and post test comparison on CBL of each module.

\begin{tabular}{|c|c|c|c|c|c|c|}
\hline S. No & Topics & $\mathbf{N}$ & $\begin{array}{l}\text { CBL-Pre-test } \\
\text { (out of } 30 \text { marks) }\end{array}$ & $\begin{array}{l}\text { CBL -Post-test } \\
\text { (out of } 30 \text { marks) }\end{array}$ & $\begin{array}{l}\text { Percentage } \\
\text { difference }(\%)\end{array}$ & t-value \\
\hline 1. & B.A & 58 & $11.54 \pm 2.75$ & $23.25 \pm 1.26$ & + $11.75(39.16)$ & $-29.48 * *$ \\
\hline 2. & A.P.D & 55 & $13.55 \pm 1.24$ & $25.58 \pm 3.22$ & $+12.03(40)$ & $-25.85 * *$ \\
\hline 3. & M.I & 57 & $15.24 \pm 3.65$ & $22.12 \pm 2.26$ & $+6.88(22)$ & $-12.99 *$ \\
\hline 4. & D.M & 54 & $19.50 \pm 2.22$ & $25.22 \pm 2.25$ & $+5.72(19)$ & $-13.29^{\mathrm{NS}}$ \\
\hline
\end{tabular}

$\mathrm{N}=$ number of participants B.A-Bronchial asthma, APD- Acid peptic disease, M.I- Myocardial Infarction and D.M- Diabetes mellitus, $* * \mathrm{P}<0.0001, * \mathrm{P}<0.005$ and NS-Not significant 
Table 2: Study participants' feedback on CBL.

\begin{tabular}{|llllll|}
\hline Five point likert scale feedback questionnaire & $\begin{array}{l}\text { Responses }(\%) \\
\text { Strongly } \\
\text { agree }\end{array}$ & Agree & $\begin{array}{l}\text { No } \\
\text { opinion }\end{array}$ & $\begin{array}{c}\text { Disagree } \\
\text { Strongly } \\
\text { disagree }\end{array}$ \\
\hline $\begin{array}{l}\text { Proper introduction was given on clinical case based } \\
\text { teaching and expected benefits }\end{array}$ & $55(91)$ & $5(8)$ & $0(0)$ & $0(0)$ & $0(0)$ \\
\hline $\begin{array}{l}\text { CBL provides more time to understand the concepts by } \\
\text { self }\end{array}$ & $45(75)$ & $10(16)$ & $2(3)$ & $3(5)$ & $0(0)$ \\
\hline CBL in groups improves communication skills & $50(83)$ & $10(16)$ & $0(0)$ & $0(0)$ & $0(0)$ \\
\hline Role of facilitator is required & $40(66)$ & $12(20)$ & $5(8)$ & $3(5)$ & $0(0)$ \\
\hline CBL creates interest to participate in group discussion & $57(97)$ & $3(5)$ & $0(0)$ & $0(0)$ & $0(0)$ \\
\hline CBL is more interesting than didactic lectures & $42(70)$ & $10(16)$ & $3(5)$ & $5(8)$ & $0(0)$ \\
\hline $\begin{array}{l}\text { CBL provides opportunity to discuss more } \\
\text { comfortably with facilitator }\end{array}$ & $35(58)$ & $23(38)$ & $2(3)$ & $0(0)$ & $0(0)$ \\
\hline $\begin{array}{l}\text { CBL method of learning is beneficial at clinical } \\
\text { settings }\end{array}$ & $44(73)$ & $12(20)$ & $0(0)$ & $4(6)$ & $0(0)$ \\
\hline $\begin{array}{l}\text { Analytical and problem solving skills were improved } \\
\text { by CBL }\end{array}$ & $32(53)$ & $22(36)$ & $4(6)$ & $2(3)$ & $0(0)$ \\
\hline Require more preparation time for CBL & $50(83)$ & $8(13)$ & $2(3)$ & $0(0)$ & $0(0)$ \\
\hline Recommend CBL for forthcoming M.B.B.S batches & $45(75)$ & $5(8)$ & $10(16)$ & $0(0)$ \\
\hline
\end{tabular}

NB: Out of 60 students, 52 were present during all the CBL sessions. The percentages are shown in round figures. CBL: Case-based learning.

In the present study with the participation of 60 undergraduate students, it was found 91 percent of students strongly agree that they understood the concept of case based learning through proper introduction with examples and 75 percent of the students believed by CBL method more time is available to follow and understand the essence of particular module and its clinical association. 83 percent of the students believed with $\mathrm{CBL}$ they are comfortable discussing among fellow students and facilitators in the free platform enabling them to improve communication skills and group dynamics. 66 percent felt the role of facilitator was vital in steering the discussion in the right path and in provoking participation from every participant. 58 percent strongly agreed and 38 percent agreed that interaction with facilitator was comfortable and provided more freedom for interaction. 97 percent of Students strongly agreed that CBL teaching method provoked interest in solving the case problem by discussion, sharing of knowledge and there by motivating self-learning. Several studies on CBL as teachinglearning method have proved to promote active participation with motivation to learn by instant feedback from facilitator and self assessment. ${ }^{6,7}$

Among 60 students, 8 percent disagreed, 5 percent did not opine whereas 86 percent of the students felt CBL teaching -learning method was more interesting than didactic lectures. Similar feedback from students was reported by parimala et al. ${ }^{8} 73$ percent strongly agreed that through CBL they are able to understand better in clinical bed side teaching. 53 percent strongly agreed and 36 percent agreed that their analytical and problem solving skills were improved by CBL. 75 percent of the participants strongly recommended CBL as a teachinglearning method for forthcoming M.B.B.S batches.

There was significant improvement in post-test performance in all the modules of CBL, with $39.16 \%$ improvement in the first module of bronchial asthma, $40 \%$ improvement in second module Acid peptic disease module, $22 \%$ in third module myocardial infarction followed by $19 \%$ improvement in the last module diabetes mellitus. The drop in percentage improvement from pre-post-tests compared to first and last module was possibly because of improved pre-test scores. This study was conducted based on positive results similar to current study as well as published by other researchers on medical education technologies which state effective learning environment can be created by specific learning objectives by case based learning. ${ }^{9-11}$

\section{CONCLUSION}

The study concludes that student centred teachinglearning process with innovative teaching methods like CBL motivates the students to actively get involved in the learning process. The improvement in pre-test scores is an indicator of change in learning behaviour and selflearning attitude and developing interest in self-learning.

\section{ACKNOWLEDGEMENTS}

We sincerely thank our II M.B.B.S Students for the participation and providing feedback.

Funding: No funding sources 
Conflict of interest: None declared

Ethical approval: The study was approved by the Institutional Ethics Committee

\section{REFERENCES}

1. Singh PR, Bhatt R. Introduction of case based learning for teaching anatomy in a conventional medical school. J Anat Soc India. 2011;60(2):232-5.

2. Srinivasan M, Wilkes M, Stevenson F, Nguyen T, Slavin S. Comparing problem-based learning with case-based learning: Effects of a major curricular shift at two institutions. Acad Med. 2007;82(1):7482.

3. Gade S, Chari S. Case-based learning in endocrine physiology: An approach toward self-directed learning and the development of soft skills in medical students. Adv Physiol Educ. 2013;37(4):356-60.

4. Jamkar A, Yemul V, Singh G. Integrated teaching programme with student-centred case-based learning. Med Educ. 2006;40(5):466-7.

5. Vyas R, Jacob M, Faith M, Isaac B, Rabi S, Sathishkumar S, et al. An effective integrated learning programme in the first year of the medical course. Natl Med J India. 2008;21(1):21.

6. Steinert Y, Snell LS. Interactive lecturing: Strategies for increasing participation in large group presentations. Med Teach. 1999;21(1):37-42.
7. Rao SP, DiCarlo SE. Active learning of respiratory physiology improves performance on respiratory physiology examinations. Adv Physiol Educ. 2001;25(1-4):127-33.

8. Parimala K, Subash KR. Assessment of pharmacology teaching. A critical appraisal by Medical school learners. Int J Med Res Health Sci. 2013;2(2):124-9.

9. West DC, Pomeroy JR, Park JK, Gerstenberger EA, Sandoval J. Critical thinking in graduate medical education: A role for concept mapping assessment? JAMA. 2000;284(9):1105-10.

10. Burrowers PA. A student-centred approach to teaching general biology that really works: Lord's constructivist model put to a test. Am Biol Teach. 2003;65:491-502.

11. Surapaneni KM. The effect of integrated teaching with Case Based Learning (CBL) in the biochemistry of undergraduate med curriculum. JCDR. 2010;5:3058-60.

Cite this article as: Britto GF, Subash KR. The effect of student centered pharmacology teaching in the form of clinical case scenario among M.B.B.S students. Int J Basic Clin Pharmacol 2017;6:458-61. 